Keywords: MST, ISDP

Retention: Permanent

\title{
Analysis of Harrell Monosodium Titanate Lot \#052511
}

K. M. L. Taylor-Pashow

August 2011

Savannah River National Laboratory

Savannah River Nuclear Solutions, LLC

Aiken, SC 29808

Prepared for the U.S. Department of Energy under contract number DE-AC09-08SR22470.

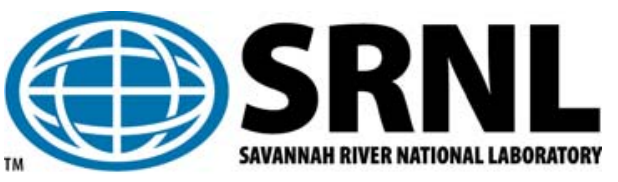


SRNL-STI-2011-00471

Revision 0

\section{DISCLAIMER}

This work was prepared under an agreement with and funded by the U.S. Government. Neither the U.S. Government or its employees, nor any of its contractors, subcontractors or their employees, makes any express or implied:

1. warranty or assumes any legal liability for the accuracy, completeness, or for the use or results of such use of any information, product, or process disclosed; or

2. representation that such use or results of such use would not infringe privately owned rights; or

3. endorsement or recommendation of any specifically identified commercial product, process, or service.

Any views and opinions of authors expressed in this work do not necessarily state or reflect those of the United States Government, or its contractors, or subcontractors.

\section{Printed in the United States of America \\ Prepared for \\ U.S. Department of Energy}




\section{REVIEWS AND APPROVALS}

AUTHORS:

K. M. L. Taylor-Pashow, Separations and Actinide Science Programs

Date

TECHNICAL REVIEW:

T. B. Peters, Separations and Actinide Science Programs

Date

APPROVAL:

S. D. Fink, Manager

Date

Separations and Actinide Science Programs

S. L. Marra, Manager

Date

Environmental \& Chemical Process Technology Research Programs

D. J. Martin, Manager

Date

H Tank Farm Engineering 


\section{EXECUTIVE SUMMARY}

Monosodium titanate (MST) for use in the Actinide Removal Process (ARP) must be qualified and verified in advance. A single qualification sample for each batch of material is sent to SRNL for analysis, as well as a statistical sampling of verification samples. The Harrell Industries Lot \#052511 qualification and 14 verification samples met all the requirements in the specification indicating the material is acceptable for use in the process. 


\section{TABLE OF CONTENTS}

LIST OF TABLES .

LIST OF ABBREVIATIONS

1.0 Introduction 1

2.0 Experimental Procedure . 1

3.0 Results and Discussion... 1

4.0 Conclusions 3

5.0 References 3

\section{LIST OF TABLES}

Table 3-1. Weight percent, $\mathrm{pH}$ and Density Results for All Samples 2

Table 3-2. Results of the Qualification Sample Analyses.

\section{LIST OF ABBREVIATIONS}

$\begin{array}{ll}\text { ARP } & \text { Actinide Removal Process } \\ \text { CSSX } & \text { Caustic Side Solvent Extraction } \\ \text { DF } & \text { decontamination factor } \\ \text { IC } & \text { ion chromatography } \\ \text { ICP-ES } & \text { inductively coupled plasma - emission spectroscopy } \\ \text { MCU } & \text { Modular CSSX Unit } \\ \text { MST } & \text { monosodium titanate } \\ \text { SRNL } & \text { Savannah River National Laboratory } \\ \text { TIC-TOC } & \text { total inorganic carbon - total organic carbon } \\ \text { VOA } & \text { volatile organic analysis }\end{array}$




\subsection{Introduction}

Harrell Industries is under contract with Savannah River Remediation to provide MST for use in the Actinide Removal Process (ARP). A 500-mL qualification sample for Lot \#052511 was sent to the Savannah River National Laboratory (SRNL) to confirm the material meets the requirements specified in the purchase specification. ${ }^{1}$

The vendor is also obligated to send verification samples from $\sim 10 \%$ or more of the pails of MST product for each lot (distributed roughly evenly through the entire lot of pails). For the verification of this lot, Harrell Industries sent 14 samples, one each from pails \#1, 10, 20, 30, 40, $50,60,70,80,90,110,120,130$, and 140 of 143 total pails.

\subsection{Experimental Procedure}

SRNL analyzed the qualification and verification samples for density, $\mathrm{pH}$, and weight percent solids. Density was measured using an electronic pipette in triplicate. The $\mathrm{pH}$ was measured by colorimetric $\mathrm{pH}$ strips, and the weight percent solids were measured in triplicate using a MettlerToledo Halogen Moisture Analyzer HG63 instrument.

Aliquots of the qualification sample were removed under mixing conditions to provide subsamples for each of the analyses. SRNL performed the following analyses: strontium $(\mathrm{Sr})$ decontamination factor (DF), volatile organic analysis (VOA), total inorganic carbon-total organic carbon (TIC-TOC), ion chromatography (IC) for fluoride, chloride, and bromide, and particle size using a Microtrac ${ }^{\circledR}$ S3500 analyzer.

\subsection{Results and Discussion}

The results of the weight percent, $\mathrm{pH}$, and density measurements are reported in Table 3-1, while the results of the additional qualification sample analyses are reported in Table 3-2. 
Table 3-1. Weight percent, $\mathrm{pH}$ and Density Results for All Samples

\begin{tabular}{|c|c|c|c|}
\hline Sample ID & $\begin{array}{c}\text { Weight \% Solids } \\
\text { (Standard Deviation) }\end{array}$ & $\mathbf{p H}^{\mathbf{a}}$ & $\begin{array}{c}\text { Density }^{\mathrm{b}}(\mathrm{g} / \mathrm{mL}) \\
\text { (\%RSD) } \\
\end{array}$ \\
\hline Qualification & $15.72( \pm 0.170) \%$ & 11.5 & $1.119(0.05 \%)$ \\
\hline Pail \#1 & $15.78( \pm 0.108) \%$ & 11 & $1.119(0.31 \%)$ \\
\hline Pail \#10 & $15.79( \pm 0.181) \%$ & 11 & $1.126(0.02 \%)$ \\
\hline Pail \#20 & $15.69( \pm 0.154) \%$ & 11.5 & $1.124(0.01 \%)$ \\
\hline Pail \#30 & $15.90( \pm 0.118) \%$ & 11.5 & $1.126(0.17 \%)$ \\
\hline Pail \#40 & $15.81( \pm 0.076) \%$ & 11.5 & $1.126(0.08 \%)$ \\
\hline Pail \#50 & $15.77( \pm 0.070) \%$ & 11.5 & $1.125(0.06 \%)$ \\
\hline Pail \#60 & $15.72( \pm 0.045) \%$ & 11 & $1.126(0.06 \%)$ \\
\hline Pail \#70 & $15.79( \pm 0.045) \%$ & 11 & $1.121(0.09 \%)$ \\
\hline Pail \#80 & $15.86( \pm 0.127) \%$ & 11 & $1.122(0.05 \%)$ \\
\hline Pail \#90 & $15.75( \pm 0.021) \%$ & 11 & $1.123(0.10 \%)$ \\
\hline Pail \#110 & $15.76( \pm 0.116) \%$ & 11 & $1.125(0.17 \%)$ \\
\hline Pail \#120 & $15.73( \pm 0.061) \%$ & 11 & $1.123(0.04 \%)$ \\
\hline Pail \#130 & $15.54( \pm 0.101) \%$ & 11 & $1.124(0.08 \%)$ \\
\hline Pail \#140 & $15.80( \pm 0.095) \%$ & 11 & $1.123(0.07 \%)$ \\
\hline Average & $15.76( \pm 0.083) \%$ & 11 & $1.124(0.21 \%)$ \\
\hline Acceptable range ${ }^{1}$ & $15-17 \%$ & $>10$ & no requirement \\
\hline
\end{tabular}

a) The uncertainty of the $\mathrm{pH}$ measurement is $0.5 \mathrm{pH}$ units.

b) Density measurements taken at $24{ }^{\circ} \mathrm{C}$.

Table 3-2. Results of the Qualification Sample Analyses

\begin{tabular}{|c|c|c|c|c||}
\hline Property & Method & Result & Specification & Pass ? \\
\hline Sr DF & Sr test & $3.51( \pm 0.243)$ & $>1.79$ & YES \\
\hline Alcohol content & VOA & $45 \mathrm{mg} / \mathrm{L}$ & $\leq 500 \mathrm{mg} / \mathrm{L}$ max & YES \\
\hline Total Inorganic Carbon & TIC & $18 \mathrm{mg} / \mathrm{L}$ & $\leq 100 \mathrm{mg} / \mathrm{L} \mathrm{max}$ & YES \\
\hline Total Organic Carbon & TOC & $18 \mathrm{mg} / \mathrm{L}$ & $\leq 300 \mathrm{mg} / \mathrm{L}$ max & YES \\
\hline Total Halides $(\mathrm{F}+\mathrm{Cl}+\mathrm{Br})$ & IC & $<15 \mathrm{mg} / \mathrm{L}$ & $\leq 100 \mathrm{mg} / \mathrm{L}$ max & YES \\
\hline Particle Size, $<0.8 \mu \mathrm{m}$ & Microtrac $^{\circledR}$ & $6.04 \mathrm{vol} \%$ & $<10 \mathrm{vol} \%$ & YES \\
\hline Particle Size, $>37 \mu \mathrm{m}$ & Microtrac $^{\circledR}$ & $0 \mathrm{vol} \%$ & $<1 \mathrm{vol} \%$ & YES \\
\hline $\begin{array}{c}\text { Particle Size, geometric standard } \\
\text { deviation (absorbance mode) }\end{array}$ & Microtrac $^{\circledR}$ & 1.87 & $\leq 3.5$ & YES \\
\hline
\end{tabular}

\footnotetext{
${ }^{\mathrm{i}}$ The alcohol content is derived from the TOC and VOA data. The VOA result gave $5.2 \mathrm{mg} / \mathrm{L}$ isopropanol. Using the conservative case that all of the remaining carbon from the TOC result was from methanol (and knowing methanol is $37.5 \mathrm{wt} \%$ carbon), we calculate the $\mathrm{MeOH}$ as $39.7 \mathrm{ppm}$. This gives a total alcohol content of $44.9 \mathrm{ppm}$.
} 
The "Particle Size, geometric standard deviation" is defined as the 50th percentile result divided by the 16 th percentile result. Microtrac ${ }^{\circledR}$, TIC-TOC, and IC results have a $10 \%$ analytical uncertainty. VOA results have a $20 \%$ analytical uncertainty. The inductively coupled plasma emission spectroscopy (ICP-ES) results used for measuring the Sr DF have an average analytical uncertainty of $10.4 \%$. Results in parentheses are derived from the standard deviation.

The TIC and TOC results are in terms of $\mathrm{mg} / \mathrm{L}$ of carbon. If we assume that the entire TIC result is carbonate, this translates to a carbonate concentration of $\leq 0.0015 \mathrm{M}$.

\subsection{Conclusions}

Analyses of the Harrell Lot \#052511 MST material indicate the material falls within the specifications required for use at ARP.

\subsection{References}

1. Specification for Purchase of $15 \mathrm{wt} \%$ Monosodium Titanate (MST) for 96-H ARP, Specification No. X-SPP-H-00012, Rev. 6, November 2010. 


\section{Distribution:}
A. B. Barnes, 999-W
D. A. Crowley, 773-43A
S. D. Fink, 773-A
B. J. Giddings, 786-5A
C. C. Herman, 999-W
S. L. Marra, 773-A
A. M. Murray, 773-A
F. M. Pennebaker, 773-42A
W. R. Wilmarth, 773-A
K. M. L. Taylor-Pashow, 773-A
T. B. Peters, 773-42A
C. A. Nash, 773-42A
M. R. Poirier, 773-42A
F. F. Fondeur, 773-A
P. R. Jackson, 703-46A
K. H. Subramanian, 766-H
E. J. Freed, 704-56H
D. J. Martin, 241-152H
M. W. Geeting, 241-152H
T. A. Le, 766-H
A. R. Shafer, 704-27S
C. K. Chiu, 704-27S
S. E. Campbell, 241-152H
S. P. Mcleskey, 241-152H
B. A. Gifford, 704-56H
R. M. Wolfenden, 704-56 H
K. L. Lang, 704-27S 